\title{
LUT
}

Lappeenranta

University of Technology

\section{Managerial sensemaking of interaction within business relationships: A cultural perspective}

Ivanova Maria, Torkkeli Lasse

This is a Post-print version of a publication

published by Elsevier

in European Management Journal

DOI: $10.1016 /$ j.emj.2013.07.007

Copyright of the original publication: Copyright @ 2013 Elsevier Ltd.

Please cite the publication as follows:

Ivanova Maria, Torkkeli Lasse. (2013). Managerial sensemaking of interaction within business relationships: A cultural perspective. European Management Journal, Vol. 31, Issue 6. p. 717-727. DOI: 10.1016/j.emj.2013.07.007 


\section{Managerial sensemaking of interaction within business relationships: A cultural perspective}

\section{Introduction}

In today's globalized business world, the role of culture seems to be diminished and underappreciated. This is partly because when considering the role of culture, academics and practitioners of business predominantly limit their perspectives to functionalistic cultural models (Leung, Bhagat, Buchan, Erez \& Gibson, 2005; Yaprak, 2008). In particular, Hofstede's perspective (1980) has gained widespread use over the last decades and has emerged as the predominant way of looking at culture (Venaik \& Brewer, 2010). This is despite the fact that such cultural models have been criticized for being inaccurate in how they are constructed (McSweeney, 2002) and structured (Fang, 2003).

Industrial business relationships studies in marketing management also predominantly regard culture from a functionalistic perspective (Fletcher \& Fang, 2006; Lowe, Carr, Thomas \& Watkins-Mathys, 2005), and look for unitary meaning (Lowe, 2002). However, this view ignores the notion that in intercultural business relationships, certain actions can hold different meanings, as individuals' cultural backgrounds and understandings are pluralistic. Lowe (2002) calls for a 'binocular' view on culture in business and management studies, focused on constitutive aspects of culture, which are socially constructed and form systems of meaning that define actors' interests.

Nevertheless, those rare studies that apply a social constructivist perspective on intercultural business interaction mostly investigate intra-organizational contexts (e.g. Shenkar, Luo \& Yeheskel, 2008). In response, we aim to contribute to extant marketing management literature, by applying a social constructivist perspective on culture in the study of business-to-business interaction within an inter-organizational context. 
Consequently, we treat culture as a system of meaningful knowledge, i.e. a repertoire of cultural schemas, used by individuals in their sensemaking of business interaction.

Culture is particularly important in business relationship interaction between managers from developed and emerging economies, as they often have contrasting understandings of managerial concepts (see Hempel 2001). Prevalent research on managerial thinking has mainly considered the view of the developed western world, while discounting the view of managers from emerging markets.

In addition, extant cultural studies in the management of industrial business relationships and interaction mostly forgo the individual perspective (Henneberg, Naudé \& Mouzas., 2010), and the cultural aspect of managerial sensemaking on business interactions. Sensemaking has been applied in industrial marketing management literature recently, but predominantly in relation to business network studies and without considering the role of culture (e.g. Henneberg et al., 2010, Colville \& Pye, 2010, Abrahamsen, Henneberg \& Naudé 2012). We further aim to contribute to marketing management literature by focusing on managers' cultural sensemaking of interaction events in dyadic business-to-business relationships and its symbolic expression.

Thus, our main objective is to understand how the cultural context imbues business relationships and interaction between managers from emerging and developed markets by addressing the following research questions: How do managers apply their cultural schemas when making sense of business relationships and interactions, and how do cultural differences arise in the sensemaking of interaction events? The present study is of an exploratory nature. Our unit of analysis is the individual manager and his/her interaction with a business partner from another cultural context. We seek to discover the differences in understanding and sensemaking of dyadic business relationships in an intercultural setting, by looking at perspectives from both sides of the dyad. Thus we further aim to fill a gap where previous studies on dyadic business relationships from a managerial perspective predominantly regarded only one side of the dyad (e.g. Leek, Turnbull \& Naudé, 2006; Öberg 2010; Tidström \& Hagberg-Anderson, 2012). 
We see Russian-Finnish business relationships as a fitting empirical context, since researchers predominantly treat Russia as an Eastern European country, while Finland is treated as a Western one (Abetti, Hirvensalo \& Kapij, 2001, Suutari, 1998). Furthermore, the Russian business environment is determined by the importance of cultural aspects in business behaviour and decision-making (Puffer \& McCarthy, 2011). Finland is a natural context for the counterpart of the business dyad, as Finnish-Russian business relationships have historically been determined by cultural differences and misunderstandings (Suutari, 1998).

In order to answer the research questions, we interpret stories from Finnish SME managers and the managers of their Russian business partners about key interaction events in their business relationships where differences in managerial sensemaking become evident. We discuss their sensemaking in light of the diverging cultural schemas applied, and the metaphors and idioms used for symbolic expression. Our findings suggest that difference in the application of cultural schemas and communication styles may lead to hidden misunderstandings and problems in business interaction. By looking at individual sensemaking of business-to-business interaction from a cultural perspective we are able to address gaps in marketing management literature and contribute to its theoretical and methodological underpinnings. Our study also adds to the growing body of literature on culturally imbued managerial sensemaking, usually conducted in an organizational context, by looking at sensemaking in an inter-organizational context.

\section{Cultural background as the differentiator in managerial understanding of interaction}

\subsection{Managerial sensemaking of interaction events}

Business-to-business relationships can be seen as "social constructions that are dynamically created, confirmed, modified and terminated by people in interaction" (Biggeman \& Buttle, 2009, p. 549). Concurrently, they represent collections of interactive events that do not necessarily follow a chronological order. These two definitions align with the notion that within business relationships and network research, 
an event may be based on individual subjective perceptions and therefore viewed from a social constructivist perspective (Tidström \& Hagberg-Andersson, 2012). Thus, in this study we see the individual manager as the key representational actor of his/her firm and business interaction in relationship dyads as constructed from inter-individual interaction, i.e., an interplay between the context, the exchange process, and its symbolic expression.

Ford and Håkansson (2006) outline five issues that are useful for understanding interaction, namely, 'time', 'interdependence', 'relativity', 'jointness', and 'subjective interpretation'. Here, we focus on the last. Subjective interpretation implies that each individual has his/her personal interpretation of the situation and might base his/her following actions on the subjective interpretation of previous actions (Ford \& Håkansson, 2006). This leads us to consider the concept of sensemaking.

Sensemaking "is concerned with the way people make bets on 'what is going on' and what to do next by way of (inter)action." (Colville \& Pye, 2010, p. 373). This paper addresses the former. Sensemaking is also the mechanism by which an individual attributes meaning to events (see Weick, Sutcliffe \& Obstfeld, 2005), e.g. those related to interaction. In turn, culture is one of the basic tools for cognitive meaning-making (Strauss \& Quinn, 1997). Thus, managerial sensemaking of interaction events, particularly in an intercultural context, can stem from an individual's cultural background.

The application of culture in sensemaking has mostly been limited to organizational contexts (Harris, 1994; Hatch \& Schultz, 2002) or to 'cultural sensemaking', focusing on the ways people make sense of others' culture, applying national culture dimensions framed as cultural stereotypes (e.g. Osland \& Bird, 2000; Bird \& Osland, 2006). Our perspective is consistent with Harris's (1994) and regards cultural sensemaking as a process in which an individual cognitively applies cultural constructs in order to make sense of an inter-organizational interaction event and ascribe meaning to it. However, we see the use of cultural constructs by managers as a largely unconscious and unintentional process and do not restrict ourselves to a view that is either a national cultural dimension or an organizational culture. Instead, we refer to culture as a repertoire of cultural 
schemas.

\subsection{Cultural schemas and their symbolic expression in managerial sensemaking}

The concept of schema relates to cognition and is defined as stocks of organized knowledge, which evolve gradually, become more complex, and are related to personal experiences and associated feelings (Van Gorp, 2007). Business scholars have predominantly applied the concept of 'organizational schemas' to sensemaking of managers, and viewed them as shared frames of reference among organization members (see Harris, 1994; Balogun \& Johnson, 2004). Nevertheless, individual schemas of managers engaged in intercultural business relationships can differ from organizational schemas, due to managers' interaction with other social groups outside organizational borders. The groups with which the individual interacts to may represent different 'cultural circles', e.g. organizational or corporate, professional, national, role, interests, as well as traditional heritage circles.

Thus, we apply the concept of 'cultural schemas' as cognitive structures that constitute knowledge for interaction in a certain cultural context (Nishida, 1999), i.e. in a certain cultural group. The individual cultural schemas might incorporate organizational, industrial, business, professional, national, and other levels of cultural knowledge, as well as inherited historical and traditional cultural knowledge. The more intercultural experience the individual has, the greater his/her repertoire of cultural schemas will be (Endicott, Bock \& Narvaez, 2003). The repertoire of cultural schemas, in turn, assists individuals when making sense of certain intercultural encounters (Friedman \& Antal, 2005) (e.g., intercultural business interaction events).

Sensemaking is also a communicative and narrative process (Balogun \& Johnson, 2004, Brown, Stacey \& Nandhakumar, 2008), where a narrative embodies knowledge, e.g. cultural, and represents a linguistic expression of sensemaking (see Brown et al., 2008). Thus, figurative language, e.g. metaphors, idioms, etc., may play an important role in how people make sense of various phenomena (Nicholson \& Anderson, 2005), emotional experiences (Boudens, 2005), and their surroundings (Landau, Meier \& Keefer, 2010). 
Landau et al. (2010, p. 1062) propose that a "metaphor-enriched perspective" is capable of explaining a large number of empirical findings that are difficult to account for with the schema view alone. Moreover, metaphors and idioms incorporating cultural beliefs and attitudes (Glucksberg 2001), can help in uncovering cultural differences in thought (Landau et al., 2010) and are at the core of symbolic expression (Lakoff \& Johnson, 2003). Thus, we see metaphors and idioms as tools allowing symbolic expression of culture in the sensemaking and bringing out the cultural schemas.

\section{Methodological approach and method of analysis}

Considering the aims and the conceptual background, we regard the narrative approach (Boje, 2001; Brown, 2006) as the most appropriate method and particularly helpful when trying to understand managers' sensemaking of their business relationships (Rhodes \& Brown, 2005; Brown et al., 2008).

\subsection{Data Collection}

The primary data was collected from top-managers involved in three dyadic relationships between Finnish SMEs and their Russian business partners. This setting was chosen since obtaining data from respondents engaged in different types of relationships creates a qualitative diversity of narratives about intercultural experiences, which is beneficial when applying a constructivist perspective on culture (see Kvale, 1996). Furthermore, only the top-management level was considered since business interaction in Russia typically occurs on high hierarchical levels. We selected the Finnish sides of the dyads based on their level of experience in business relationships with Russian firms. We then contacted the Finnish firms' representatives and obtained from them their most relevant Russian contact. The choice of the Russian partner was based on the prominence of the contact's importance and the high level of that interaction.

Altogether, seven semi-structured interviews were conducted during June and August 2012 within the selected firms' premises in Finland and in the Saint Petersburg's area, Russia. We encouraged the respondents to share stories about their business relationship 
development with narratives about key interactive events. We avoided the use of the word 'culture' in the conversations, as the aim was to look at how the respondents unintentionally use their own cultural schemas in the construction of interaction events. The interview guide (see appendix 1 for selected items) acted as an initial trigger for the respondents' storytelling, rather than a strictly followed protocol. Interviews were conducted in Finnish and Russian respectively and lasted ca. 9 hours in total, varying between 1 and 2.5 hours. The taped interviews were transcribed verbatim.

We subsequently excluded the third dyad from our analysis, because it provided a different cultural setting for the interaction as a bicultural manager handled the business relationship from the Finnish side. While such a bicultural setting in a business relationship might provide several fruitful research avenues (see for example Shanahan, 1996), it was inconsistent with the focus of our study. Table 1 demonstrates the characteristics of the two remaining dyads.

Table 1 Firms' characteristics.

\begin{tabular}{|c|c|c|c|c|c|c|}
\hline & Name & Specialisation & $\begin{array}{l}\text { Year of } \\
\text { incor- } \\
\text { poration }\end{array}$ & $\begin{array}{c}\begin{array}{c}\text { Number } \\
\text { of } \\
\text { employees }\end{array} \\
\end{array}$ & $\begin{array}{l}\text { Experience in Finnish- } \\
\text { Russian relationships }\end{array}$ & $\begin{array}{l}\text { Type of } \\
\text { relationship } \\
\text { contact }\end{array}$ \\
\hline \multirow{2}{*}{$\frac{7}{\widetilde{z}}$} & FinnFilt & $\begin{array}{l}\text { Manufacturer of } \\
\text { industrial filters and } \\
\text { ventilation applications } \\
\text { customized for customer } \\
\text { needs }\end{array}$ & 1995 & 12 & High (started in 2004-2005) & \multirow[t]{2}{*}{$\begin{array}{l}\text { Top-manager- } \\
\text { level } \\
\text { (Seller - Buyer/ } \\
\text { Distributor } \\
\text { relationships) }\end{array}$} \\
\hline & RusVent & $\begin{array}{l}\text { Manufacturer and } \\
\text { distributor of } \\
\text { ventilation, air cleaning, } \\
\text { welding and cutting } \\
\text { solutions. Distribution } \\
\text { (for FinnFilt) since } 2010\end{array}$ & 1989 & 700 & $\begin{array}{l}\text { High (First contacted FinnFilt } \\
\text { in } 2000 \text { - first company in } \\
\text { Finland for them) }\end{array}$ & \\
\hline \multirow{2}{*}{ 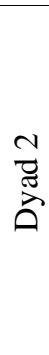 } & $\begin{array}{l}\text { FinnMac } \\
\text { hines }\end{array}$ & $\begin{array}{l}\text { Manufacturer of } \\
\text { machinery for timber } \\
\text { house industry }\end{array}$ & 1974 & 20 & $\begin{array}{l}\text { High (RusMachineDist since } \\
\text { 2006; In Russian business } \\
\text { since ca.1999) }\end{array}$ & \multirow{2}{*}{$\begin{array}{l}\text { Top-manager- } \\
\text { level } \\
\text { (Seller-Buyer/ } \\
\text { Distributor } \\
\text { relationships) }\end{array}$} \\
\hline & $\begin{array}{l}\text { RusMach } \\
\text { ineDist }\end{array}$ & $\begin{array}{l}\text { Manufacturer and } \\
\text { distributor of ready } \\
\text { made mechanical } \\
\text { engineering products }\end{array}$ & $1995 / 1996$ & 20 & $\begin{array}{l}\text { High } \\
\text { (First contacted } \\
\text { FinnMachines in 2002, } \\
\text { started working since } \\
\text { 2004/2005) }\end{array}$ & \\
\hline
\end{tabular}

The investigated firms represented construction and engineering industries. The names of companies and respondents have been altered in order to preserve confidentiality. Table 2 
presents the general cultural background of the respondents.

Table 2 Respondents' background.

\begin{tabular}{|c|c|c|c|c|c|c|}
\hline & Name & Company & $\begin{array}{l}\text { Organizational } \\
\text { culture }\end{array}$ & $\begin{array}{l}\text { Role } \\
\text { Culture }\end{array}$ & $\begin{array}{l}\text { Professional } \\
\text { culture }\end{array}$ & $\begin{array}{l}\text { Inherited } \\
\text { national } \\
\text { culture }\end{array}$ \\
\hline \multirow[b]{2}{*}{ "ָ } & Joonas & FinnFilt & $\begin{array}{l}\text { Finnish small } \\
\text { business }\end{array}$ & $\begin{array}{l}\text { Founder/ } \\
\text { Managing Director }\end{array}$ & Engineering & Finnish \\
\hline & Leonid & RusVent & $\begin{array}{l}\text { Medium sized } \\
\text { with Swedish } \\
\text { roots }\end{array}$ & Technical director & Engineering & Russian \\
\hline \multirow{2}{*}{ 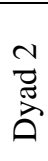 } & Seppo & $\begin{array}{l}\text { FinnMachin } \\
\text { es }\end{array}$ & $\begin{array}{l}\text { Finnish small } \\
\text { business }\end{array}$ & $\begin{array}{l}\text { Owner/ } \\
\text { Managing Director }\end{array}$ & Engineering & Finnish \\
\hline & Petr & $\begin{array}{l}\text { RusMachine } \\
\text { Dist }\end{array}$ & $\begin{array}{l}\text { Russian small } \\
\text { business }\end{array}$ & $\begin{array}{l}\text { Owner \& Founder/ } \\
\text { CEO }\end{array}$ & Engineering & Russian \\
\hline
\end{tabular}

In both dyads, the business relationship development contains a major key event considered crucial by the respondents (see fig. 1). In dyad 1, the major event occurs early on in the relationship, when business transactions between the firms constructed a buyerseller relationship. In contrast, the major event in dyad 2 relationship occurs later, after the type of relationship changed from buyer-seller to seller-distributor. Thus we expected to obtain narratives during different phases of the overall relationship timeline.

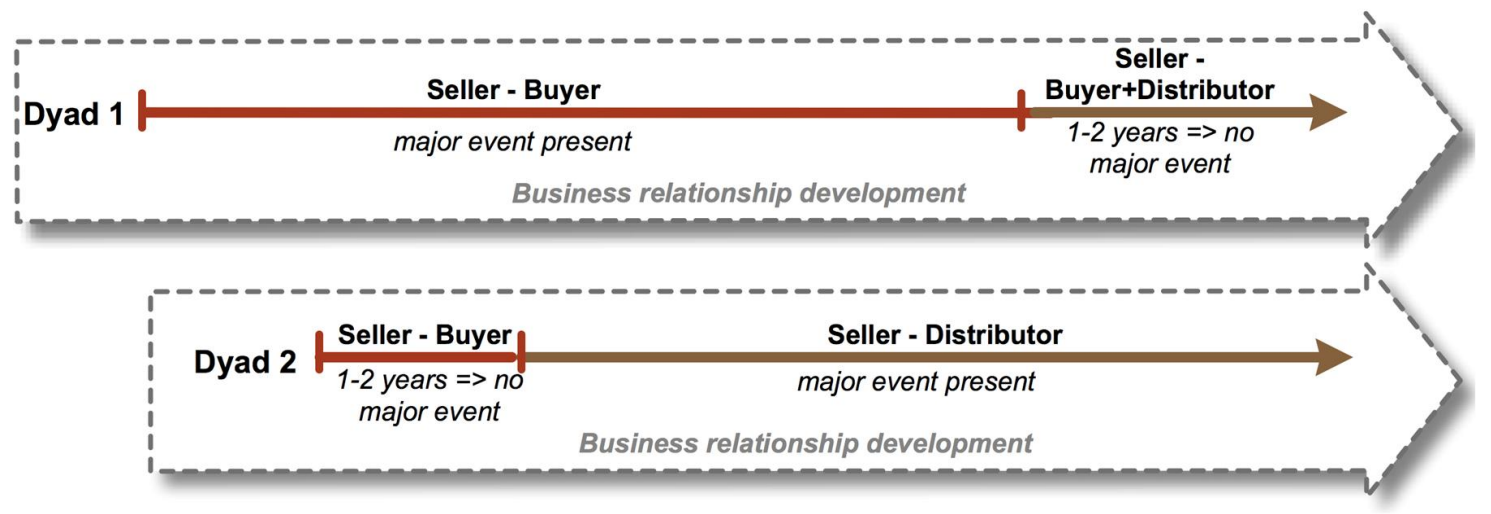

Figure 1 Characteristics of dyadic business relationships development over time.

\subsection{Data analysis}

The narratives were interpreted through cultural and language lenses with the analysis considering the original language, as stories told in the original language are more 
emotionally intense (Pavlenko, 2007). Furthermore, the authors of this study are of Russian and Finnish origin respectively, which adds credibility to the cultural interpretation of the data. We primarily focused on the elicitation of metaphors used as cultural and symbolic artefacts in respondents' sensemaking and on a contextual approach to their interpretation (see Cornelissen, Oswick, Christensen \& Cornelissen, 2008). Similarly to Pragglejaz Group (2007) method we identified metaphors in the narratives by comparing the lexical units' meaning in the context of the narratives with its basic meaning (for an example see appendix 2).

The analysis of the individual narratives consisted of the following steps. First, we reviewed the whole narrative looking for its general sense. Second, we re-read the narrative and outlined the interaction events particularly emphasized by the respondents. We also attempted to find contrasting perspectives from the respondents on the same event. Third, metaphors were identified within the individual narratives of particular events. In the course of metaphor elicitation some idioms were also discerned and further considered. Discerned metaphors and idioms were interpreted thoroughly in relation to the context, outlining the underlying cultural schemas.

Further, as the use of metaphors and idioms in respondents' sensemaking was lacking, we conducted a structural analysis of the selected narratives (Labov \& Waletzky, 1967) so as to include all the interaction events emphasized as important by the respondents. Labov and Waletzky (1967) outlined six structural components of a narrative: "abstract (what the story is about); orientation (time, place, situation, participants); complicating action (what actually happened); evaluation (the "so what"); resolution (what finally happened); and coda (the ending and exit)" (Makkonen, Aarikka-Stenroos \& Olkkonen, 2012, p. 291). We particularly focused on the 'evaluation' component (the "so what"), as it contains the meaning of the narrative (Huberman \& Miles, 2002), and thus allows understanding the cultural schemas applied. Within the narratives presented in the results section the 'evaluations' are highlighted in bold, while metaphors and idioms are in bold with double underlining.

\section{Results}




\subsection{FinnFilt and RusVent: Manager-level interaction in the buyer-seller relationship and further distribution relationship.}

\subsubsection{Event 1 - Beginning of the business relationship}

The business relationship between FinnFilt and RusVent began as an initiative from the Russian side:

"Actually they were looking for suppliers in Finland and we were lucky enough to be asked to cooperate with this particular company...It was when they contacted us that we started to do our research about this particular company... We used the local business services centre." - Joonas, Managing director at FinnFilt

The 'luck' of FinnFilt was embodied in a particular person, not mentioned by Joonas, but appearing in Leonid's story:

"A person with knowledge of Finnish language has worked in our company and I asked him to look for something else [for other suppliers]... We considered several companies in Finland and this young man [person] somehow knew Joonas...and advised to consider FinnFilt. And so we have met..." - Leonid, Technical director at Rus Vent

In these two narratives, the difference in the cultural schema for obtaining information appears, corresponding with earlier studies indicating that Russian managers rely more on interpersonal information (Ayios, 2004), while Finnish ones, may rely more on official sources (Hurmerinta-Peltomäki \& Nummela, 2004). Moreover, this difference arises from contrasting levels of official information transparency, and consequently, diverging levels of trust towards this type of information; in Russia trust towards official information is particularly low (Puffer \& McCarthy, 2011).

\subsubsection{Event 2 - The initial event in the buyer-seller relationship}


After becoming acquainted with each other, the partners started to discuss buyer-seller issues. The following narratives depict how this interactive event occurred.

"Our Finnish colleagues made a sample for us...If we understand that the price is ok for us, we further go on to the technical issues. If the technical issues are ok, we then buy a sample and test it here. If this sample meets our quality requirements and the parameters are the same as promised, then we sign a contract." - Leonid, Technical director at RusVent

"When we found out which type of company we are dealing with and after they [RusVent] had tested our supply assurance and quality, the cooperation changed quickly, and now we just have to bow down to them when they come and visit us." Joonas, Managing director at FinnFilt

Leonid's narrative refers to a traditional Russian cultural schema of verifying information even if it is seemingly trustful and can be depicted by the Russian proverb: "Trust, but verify". Moreover, his narrative reflects the cultural schema of the Russian consumer, which includes price-consciousness. The metaphor "bow down to..." in Joonas's sensemaking also vividly depicts the type of gratefulness and respect FinnFilt felt after recognizing the benefits of cooperating with such a successful actor in the Russian market.

\subsubsection{Event 3 - Constructing the key event in the business relationship}

The main key event in the buyer-seller relationship for Leonid was an order for one of their products, which needed a FinnFilt sub-product:

"Recently we had orders on one of our products... I told Joonas and he could not confirm, there was no answer from him for a while. I say to him "write me, what are the problems", he says "I have problems with the material". Then I say to him "Then say it to me, because I can not wait...” - Leonid, Technical director at RusVent 
For Leonid, the criticality of the event was derived from his perception of Joonas not being open about problems, in a sense that Leonid had to basically pull out the information from Joonas. Herein 'not being open' does not necessarily imply hiding information, but relates to the partners' view on the necessary extent of being elaborate on certain issues in business relationships (see Eisenberg \& Witten, 1987). This reflects the cultural schema of business relationships in Russia, where they are very much based on close personal interaction and expectations of openness between partners about their issues, such as the delivery problems mentioned above. In contrast, Finnish business partners may achieve this level of openness only after knowing each other for many years or having a friendship outside of the business context. Additionally, the pace of business in Russia is slightly different that in Finland, leading to an increased pressure to act quickly.

Elaborating on his sensemaking of the key event, Leonid made a comparison with his experiences with a German partner company where the representative was a native Russian: "you can say to him "come on, son, move quickly"...but he understands, he has the [Russian] mentality". "Come on, move quickly" is a literal translation of the Russian "sheveli bystro" and is a casual expression used with friends. The German manager has an inherited Russian mentality and thus understands the culturally based familiarity expressed by Leonid through informal communication. However, Leonid further mentioned he does not consider this communication style as appropriate to use with his Finnish partner, due to cultural differences.

In contrast, Joonas considers the key event in their relationship to be the need of RusVent to develop new products with FinnFilt's help. In his narrative, he cites rising volumes of manufacturing cooperation as the driver for RusVent to have suddenly sought increased in-house production. Through his discussions with Leonid, Joonas conveyed his view that if RusVent were to start in-house production, they would fail in some of the R\&D development that the collaboration with FinnFilt had enabled. Joonas perceives the motivation of RusVent in this event to stem from a do-it-yourself attitude and profit maximization: 
“They've had to develop a new product into the market, leading us together through how much space they have, after which we have designed a product for them ... We usually send them about one truck load of products each month but this time the volumes were really high ... As they sold spare parts, they were calculating that they could sell the parts to most of the existing machines in the market, as they know the specifications... I told them that even a car salesman knows who he has sold cars but does not still sell tires to them." - Joonas, Managing director at FinnFilt

The idiomatic expression used in Joonas's story vividly describes his view on the partner's actions in this event. In Finnish culture a "car salesman" is perceived as a person who is cunning and will sell anything. In Joonas' story, the expression contains a powerful implication of "even a car salesman" is not willing to sell everything and this is his critique of RusVent planning to do so. In his sensemaking, Joonas applies the Finnish cultural schema of conducting business, in particular the schema of strategic long-term orientation. A Latin expression commonly used in Finnish says: "The shoemaker should constrict himself to his last" (implying "every man to his own trade"). In this schema, trying to produce everything possible is perceived as leading to an inferior quality of offerings. The implied assumption that one should focus on a few things and try to be good at doing them to the best of your ability is related to the Finnish idea of core competences in business (Prahalad \& Hamel, 1990).

\subsubsection{Event 4 - Standard deliveries in business relationships}

Another minor event refers to standard deliveries where a slight misunderstanding seems to have occurred between Joonas and Leonid.

"Sometimes he [Joonas] does not know our Russian reality. There is [a sudden] surge [in sales] ... [for example] we have many customers from the budget, depending on the budget. During the first quarter there are always less orders, until the budget is approved, until it reaches the holders of the money... the third and fourth is always much higher. Well, knowing this for years, you can prepare for the third and fourth quarter and keep something in stock. But he asks "What surge?" I answer: "it's been ten years 
like that, the third fourth quarter is always higher, therefore it is necessary to keep something in stock"...and then he begins "Well, wait a minute; I have a problem with the material”.”- Leonid, Technical director at RusVent

Joonas's sensemaking of these standard delivery situations adds to the holistic picture of the event and corresponds with the 'surprise' perception interpreted by Leonid:

"They have not always remembered to inform us on time about bigger orders so we haven't always been aware of the possible risks. The boat cargo from Japan takes between 4 to 5 weeks meaning that you will get delays if you are not able to plan ahead." - Joonas, Managing director at FinnFilt

Here the meaning of Russian bureaucratic actions within institutionally dependent companies comes to the fore. The phrase "customers depending on budget" in Leonid's narrative reflects the institutional culture of Russia and the related schema. Approximately at the beginning of each calendar year, accounting departments of institutionally dependent Russian companies present budget reports for the previous calendar year to the federal tax offices. During this period production diminishes, while by the middle of the year it systematically returns to higher levels. Leonid does not understand why Joonas cannot remember that sales in the second part of the year are always higher, because Joonas has been doing business with RusVent for some time. Joonas, on the contrary, cannot understand why Leonid does not remind him about this issue every year. Indeed, in their narratives, neither of them is making an effort to understand the other.

\subsubsection{Event 5 - Development of the business relationship towards a distribution function}

In 2009-2010, FinnFilt and RusVent's business relationships developed a new role for RusVent, i.e. distribution. In contrast to the beginning of the relationship, the initiative now came from the Finnish side of the dyad. Leonid relates how the relationship developed concerning this distribution role in the following manner: 
"Joonas has told us already long time ago: "it is good what I do for you”, but his core business is filters of gas turbines and he was saying "Let's! Let's! [develop business]" Well, it was another market segment for us, but with time, we realized that this market segment is quite interesting. Well, and the more points of contact we have, the more interesting is to work together, so we decided to give it a try...And of course he was interested in us as a strong sales structure, which has branches all over [Russia]..." Leonid, Technical director at RusVent

'Points of contact' is a metaphor, which can be related to the Russian cultural schema of human relationships. The meaning behind this metaphor implies that the more points of contact between two individuals, the stronger their relationship. In our case these are the points forming additional cooperation between RusVent and FinnFilt. RusVent's motivation to expand the business reflects its corporate cultural schema of having an extensive range of offerings. Moreover, the experiences of the RusVent's owner, who lived for some time in the US, may have left some traces of American business culture its corporate culture. This type of thinking also refers to the cultural schema of Russian capitalist managers. The notion of a capitalist manager emerged in Russia at the end of 19th century and the main aim for this type of manager was commercial benefit (Zarubina 2004).

"If we [Russians] see that we can gain profit we will 'throw the cap over the mill'...if there is a particular business activity and I see that it can give us some piece of profit, we engage ourselves in this activity" - Leonid, Technical director at RusVent.

"Throw the cap over the mill" is a translation from the Russian "pustit'sya vo vse tyazhkie", a idiomatic expression for a person acting opportunistically without consideration for others. While the quote above does not necessarily imply that RusVent did not care about the interests of their business partners, the expression used vividly depicts how they prioritise profitability over other business relationship aspects. 
Although Joonas mostly forgoes talking about distribution activities, he also mentions how the cooperation in this new activity started:

"We started to develop our business with them for about a year ago. As their organization is operating nationally we included nuclear power plant filters in our cooperation. We still have a lot to learn there, as they are not professionals in that field...."- Joonas, Managing director at FinnFilt.

Joonas's sensemaking corresponds with Leonid's narrative. He pinpoints RusVent's 'strong sales structure' as the motivator for developing the business relationships further. Furthermore, his sensemaking corresponds with FinnFilt's corporate cultural schema of internationalization as a way for a small company with a small domestic market to achieve growth.

\subsubsection{Event 6 - Initial operations in the distribution-seller relationship}

The initial event in the seller-distribution relationship concerned a mutual attempt to solve the problem of selling FinnFilt's products to the Russian customer.

"What I'm trying to discuss with them at the moment is that they need to lobby the power plant managers proactively and sell them the idea of savings worth of millions of euros." - Joonas, Managing director at FinnFilt

"Sometimes, the customer wants to have something cheaper and still does not look at the quality that much ...Well, what can I say, there's a huge responsibility. The turbine itself is worth millions of dollars or euros...So if people worked with Siemens turbines, they try to get a recommendation letter from Siemens on who [company producing filters] they recommend...Although me and Joonas have the letters of recommendation, and so on, our [Russian] engineers are afraid to take on this responsibility..." - Leonid, Technical director at RusVent 
Here differences appear between the consumers' cultural schema in Finland and Russia, which Joonas is also well aware of. Nevertheless, Joonas's sensemaking in the aforementioned quote is related to the Finnish consumer culture. It can be depicted by a Finnish proverb: "The poor can't afford to buy cheap", implying that it is better to invest in something more expensive if it can save money in long-term. Nevertheless, Russian consumers are generally more price-conscious, as is reflected in Leonid's story.

Another part of Leonid's narrative refers to the Russian cultural schema of responsibility avoidance. Badmaeva and Timofeeva (2010, p. 74) specifically name this feature of Russian mentality as "unwillingness to take responsibility for his/her own fate". In our case, it refers to a much higher responsibility, i.e. the fate of the company. As Joonas confirms: "in Russia the customer might not have the courage to divert from the specifications set by the original supplier".

\subsection{FinnMachines and RusMachineDist: Manager level interaction in the buyer-seller relationship and further distribution relationship.}

\subsubsection{Event 1 - Beginning of the business relationship}

As in the case of dyad 1, the business relationship started as an initiative from the Russian side. Petr, together with his companion, had just established RusMachineDist and needed equipment to start their business. They contacted FinnMachines to solve this problem as they had already had contact with the firm in the person of a bicultural manager:

"So ... he [Petr's companion] knew the company FinnMachines and we so to say at my companion's suggestion, began to talk with Elena... Very quickly, we formulated our wishes, all this was done in a form of proposal, then was the contract and in 7 or even 6 months the production line was made." - Petr, CEO at RusMachineDist

"In this case it was our partner contacting us, but we knew each other from before. There were two persons, both working for our customers and then they started their own 
business... We started quite quickly, just to see how things will turn out... We had a very good base for trust building...." - Seppo, Managing director at FinnMachines

Before starting their own company, both Petr and his companion worked for companies who were engaged in business relationships with FinnMachines, and therefore both Seppo and Petr had previous knowledge of each other. Moreover, the presence of a native Russian intermediary at FinnMachines in the beginning of the business relationship led the two parties to have similar cultural schemas for obtaining information, allowing mutual trust on the basis of personal contacts and informal information. Subsequently, the role of the intermediary became restricted to discussing technical details with the corresponding technical director at RusMachineDist. However, as Seppo noted the presence of the intermediary was "not crucially important" and thus information obtained only from Seppo and Petr was considered feasible for the purposes of this study.

After being in a buyer-seller relationship for some time, RusMachineDist became FinnMachines' distributor. According to Seppo, the main motive for FinnMachines to engage in a seller-distributor relationship was the high-level of knowledge about their business and products by the co-owners of RusMachineDist. However, Seppo mentioned that FinnMachines did not give any exclusive rights to RusMachineDist in distribution operations and that FinnMachines also welcomes customers who want to deal directly with them. Thus, Seppo perceives RusMachineDist as the 'other' without fully relying on it as a 'friend', and is liable to guard his company image when interacting with Petr.

\subsubsection{Event 2 - The initial operations in the distributor-seller relationship}

An important event for Petr was the first sale of FinnMachines' products to the final customer, a process in which both Petr and Seppo participated. Although Seppo also noted the importance of this event, he did not elaborate a related story, and thus it is represented here from the Russian perspective. The narrative on this event appeared with Petr relating the importance of discounts for Russian customers, and the inability of Finnish companies to make a mark-up in price in order to enable a considerable discount. 
"The [Russian] mentality is such, that it is necessary to bargain...Everyone knows that FinnMachines has an expensive equipment, highly efficient, fancy, but expensive. But our people [Russians] want a discount.....Everyone comes to us and say "well, we're a very well-known company, so when you sell equipment to us, you are basically doing a favour to us, and in turn we make you sort of an advertisement just by our name, by the fact that we bought from you". Indeed, when we delivered the first product ...in 2006, it was really like that...And we were very much choked by this company. This was a bargain when we even sacrificed part of our commission in order to sell the first product in Russia ...which we normally never do. We counselled together with Seppo, groaned, snuffled, then sold the product." - Petr, CEO at RusMachineDist

Petr's vivid narrative demonstrates the price-consciousness aspect of Russian customer culture. "Choked by..." is used here as a metaphor, illustrating the extreme importance of price benefits for the Russian customer. In his sensemaking, he also uses the Russian cultural schema of business negotiation, where uncompromising, tough bargaining is considered an integral part of business transactions (Roemer, Garb, Neu \& Graham, 1999, Adair et al., 2004).

\subsubsection{Event 3 -Constructing the key event in the business relationship}

An interaction event where Petr's and Seppo's views diverge is related to the manner of acting towards the final customer and the way of conducting business in general.

"I have noticed that it has been difficult to do sales there, which has had an impact on our partner's business as well and they have started to look for alternative ways of making money, meaning that we are not their only client... Sometimes it has been a bit difficult to try to control their doings or try to make them focus on our business... ... When we think that they should be putting all their efforts on some particular customer they reply that they're are not worth the time invested in them...there have been customers who have not liked the way our partner operates, perhaps they have sensed that our partner is not listening to their needs. So in those cases they have contacted us directly”. - Seppo, Managing director at FinnMachines 
As this narrative illustrates, Seppo sees the profit-making schema of the Russian partner as a problematic issue. Similar to the Finnish manager in dyad 1, Seppo uses the Finnish cultural schema of long-term orientation in business strategies, i.e. the need to focus on a few things in order to be effective. The Russian manager's perspective on this issue is different:

"For us, it is important to have all the blocks, so that a customer comes and for example says, 'I want house-building" and we can then offer everything." - Petr, CEO at RusMachineDist

Petr means "all the blocks" metaphorically, implying that they want to have all the components from their industry in their sales assortment. This is also related to the cultural schema of profit-orientation, common in Russian business (Huber \& Wörgötter, 1998). However, the desire to 'have it all' from Seppo's perspective leads to a lack of proper consideration of customer's needs and wants crucial to a Finnish orientation towards customers and the view of internationally operating Finnish firms (Ruokonen, Nummela, Puumalainen \& Saarenketo, 2008). Petr sees this issue in a slightly different way:

"We always are a link between FinnMachines and the customer and we managed till now not to be a broken phone so to say, but rather to translate the mentality... It relates for example to the question of speed, when people ask to answer the question immediately and they necessarily require the Finns to reply them, not us ... Quite often it is something completely not relevant... Then we explain them that we are doing this job for already 7 years and it is not necessary to torture the Finnish manager, we are more competent to answer some questions ourselves... So we do not even bother them [FinnMachines] with such balderdash, we try not to, because we know that they will answer it in all seriousness and it is not necessary to answer this question at all, for example." - Petr, CEO at RusMachineDist 
In his sensemaking, Petr uses the Russian business cultural schema of the need to act quickly on the market. Idiomatic expression as "bother them with such balderdash" and "torture" metaphor imply an attitude towards customers that Seppo sees as inconsiderate, but Petr regards as an ability to read the local business culture. Thus, RusMachineDist filters the customers' feedback by importance without consulting FinnMachines in order to cope with the bustling Russian market.

However, this attitude may also lead to neglecting the customer's best interests. As Petr mentions, the Finnish manager would answer customer's question "in all seriousness", which corresponds to the Finnish business culture schema of acting in a customeroriented manner. Implicit in this schema is the idea that every question of a customer requires considerable attention and a detailed answer. Our interpretation of this event is that in the Finnish cultural schema a "customer" is not a "friend" as the Russian business culture schema assumes (Ayios, 2004, Weck \& Ivanova, 2013), implying that halfserious answers are not warranted.

\subsubsection{Event 4-Standard deliveries in the business relationship}

Petr perceives that they have conducted 'the cultural interpreter' role quite well so far, as the idiomatic expression "managed not to be a broken phone" in his previous narrative suggests. Further, Petr tells a story where he thinks their assistance played a positive role in solving a conflict situation between FinnMachines and the final customer.

"There was a situation where one Finnish manager almost ruined a contract [between FinnMachines and a customer]... Exactly because of this kind of a 'translation' problem and some strange principles...The conflict was in...reluctance to meet [the customer] halfway ...We watched everything from aside... We see that the customer begins to communicate angrily with us... After we did our work, it was necessary to connect all the cables, configure all, drive stuff here and there and that is were where the difficulties...but they can be eliminated in a day or two. But the manager bluntly stressed...that "it is not our problem"... People slowly began realizing ... it is not their fault, they began to slowly go mad..." - Petr, CEO at RusMachineDist 
While Petr recounted that they eventually solved the problem through negotiations between managements, this event illustrates the importance of having a "cultural interpreter" such as RusMachineDist when operating in the Russian market. Petr uses the idiomatic expression "translation problem" in a metaphorical sense, referring to cultural misunderstandings. Further sensemaking of the event and the usage of idiomatic expression "meet halfway" illustrates that, in his view, the main problem was in the Finnish manager's resistance towards cultural adaption.

\section{Discussion and Conclusions}

\subsection{Summary of research findings}

The main aim of this paper was to understand how cultural contexts imbue business relationships, and in particular how managerial sensemaking of interaction events differs between cultural contexts. Table 3 summarizes the main differences in cultural schemas used by managers in their sensemaking. The highlighted cultural schemas were used in narratives of at least two managers.

Table 3. Main differences in cultural schemas used in managerial sensemaking.

\begin{tabular}{|c|c|c|c|c|}
\hline & \multirow{2}{*}{\multicolumn{2}{|c|}{ Interaction events }} & \multicolumn{2}{|c|}{ Cultural schemas used in sensemaking } \\
\hline & & & Russian & Finnish \\
\hline \multirow{4}{*}{ 氞 } & \multirow{4}{*}{ 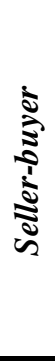 } & \multirow{2}{*}{$\begin{array}{l}\text { Beginning of business } \\
\text { relationships }\end{array}$} & $\begin{array}{l}\text { Obtaining } \\
\text { information }\end{array}$ & $\begin{array}{l}\text { Obtaining formal information } \\
\text { from Finnish consultancies }\end{array}$ \\
\hline & & & $\begin{array}{l}\text { Personal contact and } \\
\text { interaction }\end{array}$ & $\begin{array}{l}\text { Relying on their own } \\
\text { bicultural manager - "insider" }\end{array}$ \\
\hline & & \multirow{2}{*}{$\begin{array}{l}\text { Initial event of buyer-seller } \\
\text { operations }\end{array}$} & Verifying the information & \\
\hline & & & Consumer price consciousness & $\begin{array}{l}\text { Respect towards the customer } \\
\text { (Customer-orientation) }\end{array}$ \\
\hline $\overrightarrow{0}$ & \multirow{3}{*}{ 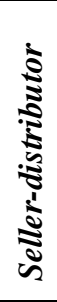 } & $\begin{array}{l}\text { Development of rel-ps } \\
\text { towards seller-distributor } \\
\text { rel-ps }\end{array}$ & Profit-orientation & $\begin{array}{l}\text { Corporate need to } \\
\text { internationalize }\end{array}$ \\
\hline & & \multirow{2}{*}{$\begin{array}{l}\text { Initial operations in } \\
\text { distributor-seller } \\
\text { relationships }\end{array}$} & $\begin{array}{lr}\begin{array}{l}\text { Consumer's } \\
\text { consciousness } \\
\text { orientation) }\end{array} & \begin{array}{r}\text { price } \\
\text { (short-term }\end{array} \\
\end{array}$ & \multirow[t]{2}{*}{$\begin{array}{l}\text { Consumer's long-term } \\
\text { orientation when investing }\end{array}$} \\
\hline & & & Bargain style of negotiations & \\
\hline & \multicolumn{2}{|c|}{ Standard deliveries in business } & Expectation & Resistance towards cultural \\
\hline
\end{tabular}




\begin{tabular}{|l|l|l|}
\hline relationships & adaptation & adaptation \\
\hline \multirow{3}{*}{$\begin{array}{l}\text { Key event in business } \\
\text { relationships }\end{array}$} & Need for openness & $\begin{array}{l}\text { Strategic long-term } \\
\text { orientation }\end{array}$ \\
\cline { 2 - 3 } & Need for quick actions & Customer orientation \\
\cline { 2 - 3 } & Profit-orientation & \\
\hline
\end{tabular}

As the cases had different characteristics in order to obtain a variety of experiences, we do not claim that the results can be generalized across all dyads between managers from emerging and developed markets, or between all managers with Finnish and Russian cultural backgrounds. However, Table 3 does illustrate some distinct patterns in the thoughts of Russian and Finnish managers about the events. Russian managers stressed the importance of informal information and personal interaction in the beginning of business relationships, as well as the importance of verifying the obtained information before starting buyer-seller operations. Conversely, the Finnish managers relied on formal information from Finnish consultancy companies or their own 'insiders'. The price consciousness of Russian customers appears to be the main problem in deliveries within seller-distributor relationships.

There also appear to be several main reasons behind cultural misunderstandings. First, the high profit- and short-term orientation of the Russian managers, contrasted with the longterm strategic planning and strong customer-orientation of Finnish managers seem to be the main conflicting schemas. Second, the expected level of openness from the partner manager may create confusion. While the Russian cultural schema includes expectations of openness from the partner about the experienced difficulties, the Finnish schema implies that the business partner is still a customer to whom a marketable image of the company must be presented.

These findings show the importance of historically bounded traditional culture in Russian managers' sensemaking, whereas Finnish managers rely on more formal western business-related cultural schemas. The need for open and interpersonal interaction can be seen to be related to one of the most crucial concepts in Russian traditional culture, 'dusha', which represents the importance of emotions in interpersonal interaction. Being able to have an 'open dusha' and 'razgovor po dusham' are vital components of interpersonal interaction and friendship in Russia (Wierzbicka 2002). 'Razgovor po 
dusham' can be translated as heart-to-heart talk and implies having unconstrained, open interaction (ibid.).

Russian cultural schemas of price-consciousness and short-term orientation may stem from traditions of bargaining and opportunistic behaviour developed over several historical instances. First, the 200 years of being ruled by the Mongols, with Russia as the center of trade between East and West, might have left the imprint of eastern bazaar traditions with the necessity to bargain. Second, the development of 19th century capitalistic manager seeking solely commercial benefit (Zarubina, 2004) (see section 4.1.5), and the unstable transition market of the 1990s might also have contributed to short-term orientation thinking.

Lastly, an additional reason for misunderstandings in inter-individual business interaction arises from the Russian expectation that the Finnish will culturally adapt, and resistance to this from the Finnish side. This is linked to the general history of relationships between Finland and Russia. During the Russian rule over Finland in $19^{\text {th }}$ century, Finns were largely allowed to retain their culture and autonomy by the Russian Tsar. However, later attempts to overturn those freedoms (known as the "Russification of Finland") in the late $19^{\text {th }}$-early $20^{\text {th }}$ century led to Finns' negative perceptions concerning cultural adaptation towards Russia, some of which remain to this day.

Another focus of this paper was on symbolic expression of sensemaking and metaphors, which, along with idioms, showed to be a useful tool in grasping cultural schemas. Table 4 presents narrative extracts with metaphors and idioms related to particular cultural schemas. 
Table 4. Narrative extracts with metaphors and idioms related to cultural schemas

\begin{tabular}{|c|c|}
\hline Cultural schemas & Narrative extracts with metaphors and idioms \\
\hline \multicolumn{2}{|r|}{ ( } \\
\hline Need to act quickly & "Come on, son, move quickly" \\
\hline \multirow{3}{*}{ Profit-orientation } & "...have more points of contact..." \\
\hline & $\begin{array}{l}\text { "If we see that we can gain profit we will 'throw the cap } \\
\text { over the mill"," }\end{array}$ \\
\hline & “...important to have all the blocks...” \\
\hline Informal information/personal contacts & $\begin{array}{l}\text { "...at my companion's suggestion..." (*literal translation } \\
\text { from Russian - “... at my companion's giving...") }\end{array}$ \\
\hline Consumer price consciousness & $\begin{array}{l}\text { "We were very much choked by this company [customer]" } \\
\text { (*about Russian desire to have a price benefit) }\end{array}$ \\
\hline Lack of customer orientation & $\begin{array}{l}\text { "...do not even bother them [the Finns] with such } \\
\text { balderdash" }\end{array}$ \\
\hline \multicolumn{2}{|r|}{ Finnish } \\
\hline Strategic long-term orientation & $\begin{array}{l}\text { "Even a car salesman knows who he has sold cars but } \\
\text { does not still sell tyres to them." }\end{array}$ \\
\hline Respect towards the customer & “...we just have to bow down to them..." \\
\hline
\end{tabular}

We noted that managers did not use many metaphors or idiomatic expressions, which can be because of their professional, techno-cultural background. However, we did not raise the issue of professional culture further, as it was similar among all the respondents and united their views in sensemaking, rather than created differences and/or difficulties in interaction. We also note that the Finnish managers applied fewer metaphors and idioms than the Russians in their narratives. This may imply that Finns are more formal and straight to the point in their sensemaking narratives compared to Russians, who tend to use more figurative speech. From a practical perspective, this highlights the importance of considering figurative language (e.g. metaphors, idioms, etc.) when investigating Russian business from a cultural perspective.

\subsection{Theoretical and methodological implications}

The results of our study lead to various theoretical and methodological implications for marketing management of business-to-business relationships. Theoretically, differences between "western" and "eastern" managers in sensemaking of business-to-business interaction events and relationships imply a need for an increasingly culture-specific 
approach to business research. By applying an individual perspective and the concept of cultural schemas, this study takes a different approach than the predominant application of functionalistic cultural models to understanding the role of culture in business relationships, related interaction, and managerial thought.

The application of cultural schemas stemming from diverging cultural contexts leads to challenges in business-to-business interaction. The challenges arise not only from the opposition of national cultural dimensions, but can also be related to the application of traditional and business cultural schemas in interaction. Furthermore, this paper confirms the importance of metaphors and idioms in encoding cultural schemas, and their importance in managerial cultural sensemaking. Thus, this paper contributes to literature on managerial sensemaking from a cultural perspective. The results also increase the understanding of business interaction management in emerging economies.

This study also implies that a narrative approach, together with the identification and interpretation of metaphors and idioms in managerial narratives, is a relevant methodological approach to enhance the understanding of inter-organizational managerial sensemaking across cultural contexts. We find this approach fruitful for future research of business-to-business interaction between managers from different cultures, as well as for business-to-business relationship research itself. However, the researcher when conducting a study applying this approach should preferably be of a similar cultural origin and highly proficient in the language of the investigated subjects. This will allow research of the phenomenon in a natural and "emic" setting without the of risk of cultural or linguistic code-switching in the process of the subjects' storytelling and enhance the credibility of cultural interpretation.

\subsection{Managerial implications}

By giving the perspective from both sides of business relationships, our findings enhance and invigorate the practical understanding of intercultural business-to-business relationships and interaction in a Finnish-Russian context. Managers engaged in intercultural business relationships use different types of learned and inherited cultural 
schemas when making sense of certain interaction situations. Nevertheless, these various cultural schemas are mainly related to ways of acting in different situations within each manager's country, and consequently embedded in that country's context.

The study also points to several distinctions between managers with their background from developed economies, such as Finland, and emerging economies, such as Russia. The use of diverging cultural schemas, a more traditional, informal one by Russian managers and a more formal, business one by Finnish managers, has implications for interpersonal communication within business interaction events between the managers of these two countries. Investigation and understanding of historically based cultural traditions and traditional cultural artefacts, e.g. proverbs, might be beneficial for managers entering Russian markets. Additionally, a western manager should develop an ability to read between the lines in communication with Russian managers.

Understanding these distinctions allows possible misunderstandings in interactions to be smoothed over between managers from Finland and Russia, and enables construction of beneficial business-to-business relationships. In particular, this study adds to the understanding of the Eastern European approach to conducting business, as well as a different way of sensemaking about these activities. Thus, we conclude that Russian business should not copy the Western approach, but develop its own.

\subsection{Limitations and further research directions}

We recognize several limitations in our study. Firstly, although the respondents were the key individuals in the dyadic business relationships, research could benefit from gaining additional information from other individuals involved in the business relationships. Secondly, a series of longitudinal interviews might be beneficial to enrich the respondents' stories with more detail. However, we do not see these limitations as undermining the research findings, as due to the social constructivist nature of the study, we viewed each respondent's narrative as a constructed social reality, i.e. a possible reality. Thus, the reader should not treat the findings as an absolute truth, but as one of several possible ways to regard the studied phenomena. 
This study can also serve as a basis for future studies. The applied methods can be extended to other similar studies on intercultural business interaction and relationships seeking an individual perspective. The next step might be applying a similar methodological approach beyond the study of intercultural dyadic business interaction, e.g. to consider larger business networks. Another fruitful research avenue would be to conduct a longitudinal study focusing on adaptation of individual repertoires of cultural schemas along a dyadic business interaction and relationship development.

Finally, the obtained cultural schemas could be tested quantitatively on a larger population, as well as qualitatively investigated for applicability and relevance in other similar intercultural contexts. In particular, an in-depth study on the opposition of traditional versus business cultural schemas in managerial sensemaking of business-tobusiness interaction in the context of other developing - developed countries could extend these results. Moreover, a study with a focus on the differences in professional cultural schemas in the sensemaking of business-to-business interaction across industries might be of interest.

\section{References}

Abrahamsen, M.H., Henneberg, S.C., \& Naudé, P., 2012. Sensemaking in business networks: Introducing dottograms to analyse network changes, Industrial Marketing Management, 41(6), 1035-1046.

Abetti, P.A., Hirvensalo, I., \& Kapij, M.I (2001). Multi-cultural entrepreneurial ventures in the former Soviet Union: case studies of Finnish and US approaches in Russia, Ukraine and the Baltics. International Journal of Entrepreneurship and Innovation Management, 1(1), 53-72.

Adair, W., Brett, J., Lempereur, A., Okumura, T., Shikhirev, P., Tinsley, C., \& Lytle, A. (2004). Culture and negotiation strategy. Negotiation Journal, 20(1), 87-111. 
Ayios, A. (2004). Trust and Western-Russian business relationships. London: Ashgate Publishing.

Badmaeva S.V., \& Timofeeva E.K. (2010). Vliyanie "rossiiskogo mentaliteta" na stil' rossiiskogo menedzhmenta. Psihologicheskaya nauka i obrazovanie, 5, 68-76.

Balogun J., \& Johnson, G. (2004). Organizational restructuring and middle manager sensemaking. The Academy of Management Journal. 47(4), 523-549.

Biggeman, S., \& Buttle, F. (2009). Coordinated interaction and paradox in business relationships. Journal of Business and Industrial Marketing, 24(8), 549-560.

Bird, A., \& Osland, J.S. (2006). Making sense of intercultural collaboration. International Studies of Management and Organization, 35(4), 115-132.

Boje (2001). Narrative methods for organizational and communication research. London: Sage.

Boudens, C.J. (2005). The story of work: A narrative analysis of workplace emotion. Organization Studies, 26(9), 1285-1306.

Brown, A.D. (2006). A narrative approach to collective identities. Journal of Management Studies, 43(4), 731-753.

Brown, A.D., Stacey, P., \& Nandhakumar, J. (2008). Making sense of sensemaking narratives. Human Relations, 61(8), 1035 - 1062.

Colville, I., \& Pye, A. (2010). A sensemaking perspective on network pictures. Industrial Marketing Management, 39(3), 372-380. 
Cornelissen, J.P., Oswick, C., Christensen, L.T. \& Cornelissen, N.P. (2008). Metaphor in organizational research: Context, modalities and implications for research Introduction. Organization Studies, 29(1), 7-22.

Eisenberg, E.M., \& Witten, M.G. (1987). Reconsidering openness in organizational communication. The Academy of Management Review, 12(3), 418-426.

Endicott, L., Bock, T., \& Narvaez, D. (2003). Moral reasoning, intercultural development, and multicultural experiences: Relations and cognitive underpinnings. International Journal of Intercultural Relations, 27, 403-419.

Fang, T. (2003). A critique of Hofstede's fifth national culture dimension. International Journal of Cross Cultural Management, 3(3), 347-368.

Fletcher, R., \& Fang, T. (2006). Assessing the impact of culture on relationship creation and network formation in emerging Asian markets. European Journal of Marketing, 40(3/4), 430-446.

Ford, D., \& Håkansson, H. (2006). The idea of interaction. The IMP Journal, 1, 4-20.

Friedman, V.J., \& Antal, A.B. (2005). Negotiating reality: A theory of action approach to intercultural competence, Management Learning, 36(1), 69-86.

Glucksberg, S. (2001). Understanding figurative language: From metaphor to idioms. Oxford: Oxford University Press.

Hatch, M.J., \& Schultz, M. (2002). The dynamics of organizational identity. Human Relations, 55(8), 989-1018. 
Harris, S.G. (1994). Organizational culture and individual sensemaking: A schema-based perspective. Organization Science, 5(3), 309-321.

Hempel, P.S. (2001). Differences between Chinese and Western managerial views of performance. Personnel Review, 30(2), 203 - 226.

Henneberg, S.C, Naudé, P., \& Mouzas, S. (2010). Sense-making and management in business networks-some observations, considerations, and a research agenda. Industrial Marketing Management, 39(3), 355-360.

Hofstede, G. (1980). Culture's consequences: International differences in work-related values. Beverly Hills, CA: Sage.

Huber, P. \& Wörgötter, A. (1998). Political survival or entrepreneurial development? Observations on Russian business networks. Post-Soviet Affairs, 14(1), 81-91.

Huberman, M.A. \& Miles, M.B. (2002). The qualitative researcher's companion. London: Sage.

Hurmerinta-Peltomäki, L., \& Nummela, N. (2004). From temporary support to systematic resource development: expert services from an SME perspective. Journal of Small Business and Enterprise Development, 11(2), 233 - 243.

Kvale, S. (1996). Interviews: An introduction to qualitative research writing, Thousand Oaks, CA: Sage.

Labov, W., \& Waletzky, J. (1967). Narrative analysis: Oral versions of personal experience. In J. Helm (Ed.), Essays on the verbal and visual arts (pp. 12-44). Seattle: University of Washington Press. 
Lakoff, G., \& Johnson, M. (2003). Metaphors we live by ( $2^{\text {nd }}$ edition). Chicago, IL: University of Chicago Press.

Landau, M.J., Meier, B.P., \& Keefer, L.A. (2010). A metaphor-enriched social cognition. Psychological Bulletin, 136(6), 1045-1067.

Leek, S. Turnbull, P.W., \& Naudé, P. (2006). Classifying relationships across cultures as successful and problematic: Theoretical perspectives and managerial implications. Industrial Marketing Management, 35(7), 892-900.

Leung, K., Bhagat, R.S., Buchan, N., Erez, M., \& Gibson, C.B. (2005). Culture and international business: recent advances and their implications for future research. Journal of International Business Studies, 36(4), 357-378.

Lowe, S. (2002). The cultural shadows of cross cultural research: images of culture. Culture and Organization, 8(1), 21-34.

Lowe, S., Carr, A.N., Thomas, M., \& Watkins-Mathys, L. (2005). The fourth hermeneutic in marketing theory. Marketing Theory, 5(2), 185-203.

Makkonen, H., Aarikka-Stenroos, L., \& Olkkonen, R. (2012). Narrative approach in business network process research - Implications for theory and methodology. Industrial Marketing Management, 41(2), 287-299.

McSweeney, B. (2002). Hofstede's model of national cultural differences and the consequences: A triumph of faith - a failure of analysis. Human relations, 55, 89-118.

Nicholson, L., \& Anderson, A.R. (2005). News and nuances of the entrepreneurial myth and metaphor: Linguistic games in entrepreneurial sense-making and sense-giving. Entrepreneurship Theory and Practice, 29(2), 153-172. 
Nishida, H. (1999). Cultural schema theory. In W.B. Gudykunst (Ed.), Theorizing about intercultural communication (pp. 401-418). Thousand Oaks, CA: Sage.

Öberg, C. (2010). What happened with the grandiose plans? Strategic plans and network realities in B2B interaction. Industrial Marketing Management, 36(6), 926-940.

Osland, J., \& Bird, A. (2000). Beyond sophisticated stereotyping: Cultural sense making in context. Academy of Management Executive, 14(1), 65-77.

Pavlenko, A. (2007). Autobiographic narratives as data in applied linguistics. Applied Linguistics, 28(2), 163-188.

Prahalad, C.K., \& Hamel, G. (1990). The core competence of the corporation. Harvard Business Review, 68(3), 79-91.

Pragglejaz Group (2007). MIP: A method for identifying metaphorically used words in discourse. Metaphor and Symbol 22, 1-39

Puffer, S.M., \& McCarthy, D.J. (2011). Two decades of Russian business and management research: An institutional theory perspective. Academy of Management Perspectives, 25(2), 21-36.

Rhodes, C., \& Brown, A.D. (2005). Narrative, organizations and research. International Journal of Management Reviews, 7(3), 167-188.

Roemer, C, Garb, P., Neu, J., \& Graham, J.L. (1999). A comparison of American and Russian patterns of behavior in buyer-seller negotiations using observational measures. International Negotiation, 4, 37-61. 
Ruokonen, M., Nummela, N., Puumalainen, K., \& Saarenketo, S. (2008). Market orientation and internationalisation in small software firms. European Journal of Marketing, 42(11/12), 1294 - 1315

Shanahan, D. (1996). From language learner to multicultural manager. European Management Journal, 14(3), 315-320.

Shenkar, O., Luo, Y., \& Yeheskel, O. (2008). From "distance" to "friction": Substituting metaphors and redirecting intercultural research. Academy of Management Review, 33(4), 905-923.

Strauss, C., \& Quinn, N. (1997). A cognitive theory of cultural meaning . Cambridge, UK: Cambridge University Press.

Suutari, V. (1998). Problems faced by Western expatriate managers in Eastern Europe: Evidence provided by Finnish expatriates in Russia and Estonia. Journal of East European Management Studies, 3(3), 249-267.

Tidström, A., \& Hagberg-Anderson, Å. (2012). Critical events in time and space when cooperation turns into competition in business relationships. Industrial Marketing Management, 41(2), 333-343.

Van Gorp, B. (2007). The constructionist approach to framing: Bringing culture back in. Journal of Communication, 57(1), 60-78.

Venaik, S., \& Brewer, P. (2010). Avoiding uncertainty in Hofstede and GLOBE. Journal of International Business Studies, 41, 1294-1315.

Weck, M., \& Ivanova, M. (2013). The Importance of Cultural Adaptation for the Trust Development within Business Relationships. Journal of Business \& Industrial Marketing, 28(3), 210-220. 
Weick, K.E., Sutcliffe, K.M., \& Obstfeld, D., (2005). Organizing and the process of sensemaking. Organization Science, 16(4), 409-421.

Wierzbicka, A. (2002). Russian cultural scripts: The Theory of Cultural Scripts and Its Applications, Ethos, 30(4), 401-432.

Yaprak, A. (2008). Culture study in international marketing: a critical review and suggestions for future research. International Marketing Review, 25(2), 215 - 229.

Zarubina, N.N. (2004). Jetika sluzhenija i jetika otvetstvennosti v kul'ture russkogo predprinimatel'stva. Obshestvennye Nauki i Sovremennost', 1, 96-105. 
Appendix 1. Interview guide (selected questions)

1. What information, initial ideas, and perceptions of the partner did you have before contacting him?

2. Could you please relate a detailed story regarding how your business relationships developed, including a description of specific interaction events.

3. Could you try and recall a few of what you consider to be the most important events in the relationships with your Russian/Finnish partner?

4. Could you please describe these in as much detail as possible (e.g. what happened during the event?; issues raised, problems that occurred, your perceptions, feelings, etc.).

5. What was the outcome of this event?

Appendix 2. Example of metaphor identification

\begin{tabular}{|l|l|l|}
\hline $\begin{array}{l}\text { Part of narrative } \\
\text { (the metaphor is underlined) }\end{array}$ & Contextual meaning & $\begin{array}{l}\text { Basic meaning } \\
\text { (from Merriam-Webster } \\
\text { dictionary) }\end{array}$ \\
\hline $\begin{array}{l}\text { We were very much choked } \text { wey this } \\
\text { company [customer] }\end{array}$ & $\begin{array}{l}\text { Indicates customer's high } \\
\text { demands (regarding price } \\
\text { discount). }\end{array}$ & $\begin{array}{l}\text { to check or block normal } \\
\text { breathing of by compressing or } \\
\text { obstructing the trachea or by } \\
\text { poisoning or adulterating } \\
\text { available air }\end{array}$ \\
\hline
\end{tabular}

